\title{
Asthma and gender impact accumulation of T cell subtypes
}

Matthew J Loza*, Susan Foster, Eugene R Bleecker, Stephen P Peters, Raymond B Penn ${ }^{*}$

\begin{abstract}
Background: The "Th2 hypothesis for asthma" asserts that an increased ratio of Th2:Th1 cytokine production plays an important pathogenic role in asthma. Although widely embraced, the hypothesis has been challenged by various empirical observations and has been described as overly simplistic. We sought to establish whether CD3 + CD28-mediated and antigen-independent accumulation of type 1 and type $2 \mathrm{~T}$ cells differs significantly between nonasthmatic and asthmatic populations.
\end{abstract}

Methods: An ex vivo system was used to characterize the regulation of IFN- $\gamma$-producing (type 1) and IL-13producing (type 2) T cell accumulation in response to CD3+CD28 and IL-2 stimulation by flow cytometry.

Results: IL-13-producing $T$ cells increased in greater numbers in response to antigen-independent stimulation in peripheral blood lymphocytes from female atopic asthmatic subjects compared with male asthmatics and both male and female atopic non-asthmatic subjects. IFN- $\gamma^{+} \mathrm{T}$ cells increased in greater numbers in response to either antigen-independent or CD3+CD28-mediated stimulation in peripheral blood lymphocytes from atopic asthmatic subjects compared to non-asthmatic subjects, regardless of gender.

Conclusions: We demonstrate that $T$ cells from asthmatics are programmed for increased accumulation of both type 2 and type $1 \mathrm{~T}$ cells. Gender had a profound effect on the regulation of type $2 \mathrm{~T}$ cells, thus providing a mechanism for the higher frequency of adult asthma in females.

\section{Background}

Asthma is frequently labeled a "Th2-like" disorder, based on an inflammatory profile in the asthmatic airway and is characterized by preferential elaboration of $\mathrm{Th} 2 \mathrm{~T}$ cells and their cytokines [1-3]. After allergen challenge, elevated levels of the type 2 cytokines interleukin (IL)-4 and IL-13 are found in the airways of asthma subjects, associated with an influx of type 2 cells and eosinophils [1-3]. The preponderance of IL-4 and IL-13 relative to the type 1 cytokine IFN- $\gamma$ is believed to promote feed-forward mechanisms of allergic inflammation in asthma. However, several observations suggest that the "Th2 hypothesis" as applied to asthma is overly simplistic. Although the ratio of type 2 cytokines to interferon (IFN) $-\gamma$ is higher in asthmatics than in nonasthmatic subjects, levels of both cytokines are often dramatically increased in allergen-challenged asthmatics $[4,5]$. Respiratory infections, known to induce IFN- $\gamma$

\footnotetext{
* Correspondence: MLoza@ITS.JNJ.COM; rpenn@medicine.umaryland.edu Department of Internal Medicine, Center for Human Genomics, Wake Forest University School of Medicine, Winston-Salem, NC, USA 27157
}

levels, have been proposed to protect against asthma development but also induce or worsen exacerbations in subjects with established asthma [1,4,6-8]. A number of studies also suggest that IFN- $\gamma$ is important in the survival and activation of eosinophils $[9,10]$.

Numerous factors regulate the accumulation of $\mathrm{T}$ cell subsets. Trafficking of $\mathrm{T}$ cells to sites of inflammation (e.g. to the airways in lungs), from peripheral blood and lymphoid tissues is one important regulatory component. Reduced numbers of regulatory $\mathrm{T}$ cells are hypothesized to influence allergen-specific increases in type $2 \mathrm{~T}$ cells in asthmatics [11]. The presence of regulatory stimuli and how $\mathrm{T}$ cell numbers increase in response to both antigenic and non-antigenic stimuli also determine absolute and relative numbers of type 1 and type 2 cells. Studies to date examining mixed $\mathrm{T}$ cell populations in vitro have characterized the effects of both antigenic, CD3-mediated and antigen-independent, bystander (e.g., IL-2, IL-15) stimuli, as well as "polarizing" effectors (IL-4, IL-12) on changes in T cell subset
Ciomed Central

C 2010 Loza et al; licensee BioMed Central Ltd. This is an Open Access article distributed under the terms of the Creative Commons Attribution License (http://creativecommons.org/licenses/by/2.0), which permits unrestricted use, distribution, and reproduction in any medium, provided the original work is properly cited. 
accumulation [12-14]. Whether $\mathrm{T}$ cells from asthmatics exhibit distinct regulatory features is not known.

To address this question we compared the regulation of $\mathrm{T}$ cell subtype accumulation in $\mathrm{T}$ cells obtained from both atopic asthmatic and non-asthmatic subjects. Our results reveal that under various conditions $\mathrm{T}$ cells from asthmatics appear programmed for increased accumulation of both type 2 and type 1 cells, and surprisingly, gender plays a role in the regulation of type 2 cells.

\section{Methods}

\section{Subject populations}

Peripheral venous blood was obtained from nonasthmatic (control) and atopic asthmatic human adults after informed consent was provided, in accordance with a Wake Forest University School of Medicine Institutional Review Board-approved protocol and the Helsinki Declaration. The criteria for being included in the atopic asthmatic population are provided in Additional File 1. All subjects refrained from taking asthma control medications at least $12 \mathrm{~h}$ prior to blood draw. Characteristics of asthmatic subjects studied in this work are presented in Table S1 in Additional File 1. Control subjects were healthy adults who had not been diagnosed or treated for asthma. All female control subjects, but $<25 \%$ of male controls, underwent clinical testing to: 1) rule out asthma (history of symptoms, reversibility of FEV1 decrement, airway hyperresponsiveness as assessed by methacholine challenge, exclusion of other respiratory disorders); and 2) evaluate atopy by skin prick test to a panel of standard common aeroallergens. For some subjects, certain outcomes were not included in analyses because of missing data resulting from insufficient cell numbers.

\section{Cell culture}

Peripheral blood lymphocytes (PBL), isolated by standard procedures [15] (>98\% lymphocytes, as assessed by flow cytometry), were cultured in RPMI-1640 media supplemented with $5 \%$ pooled human plasma. Before culture (day 0), after 5 -d culture with $50 \mathrm{U} / \mathrm{ml}$ recombinant human IL-2 + IL-12-neutralizing monoclonal antibody ( $\alpha$ IL-12) + CD28 monoclonal antibody + CD3 monoclonal antibody (plate-bound), or after 6 -d culture with $50 \mathrm{U} / \mathrm{ml} \mathrm{IL-2} \mathrm{+} \mathrm{IL-12-neutralizing} \mathrm{monoclonal}$ antibody, cells were collected and assessed for viability and cell numbers with an automated cell counter (ViCell, BeckmanCoulter). Anti-IL-12 mAb was included to exclude any influence of IL-12 potentially released from the few contaminating monocytes (see Loza et al. [16]). For " $\mathrm{T}_{\mathrm{H}} 2$-polarized" cultures, $50 \mathrm{U} / \mathrm{ml} \mathrm{IL-2,} 5 \mathrm{ng} /$ $\mathrm{ml} \mathrm{IL-4}$ and IL-12-neutralizing monoclonal antibody were included in the $\mathrm{CD} 3+\mathrm{CD} 28$-stimulated cultures described above. For " $\mathrm{T}_{\mathrm{H}} 1$-polarized" cultures, $50 \mathrm{U} /$ $\mathrm{ml} \mathrm{IL-2,} 2 \mathrm{ng} / \mathrm{ml} \mathrm{IL-12,} \mathrm{and} \mathrm{TNF-} \alpha$-neutralizing monoclonal antibody were included in the CD3+CD28stimulated cultures described above (but without IL-12neutralizing monoclonal antibody). See Additional File 1 for additional details about culture conditions.

\section{Cytokine production}

After culture and counting an aliquot of cells, 2-4 × $10^{6}$ cells $/ 250 \mu \mathrm{l}$ were stimulated for cytokine production (5-h with $2 \mathrm{nM}$ phorbol myristate acetate (PMA), $0.2 \mu \mathrm{g} /$ $\mathrm{ml}$ calcimycin, $100 \mathrm{U} / \mathrm{ml} \mathrm{IL-2,} 5 \mu \mathrm{M}$ monensin). Intracellular IL-13 and IFN- $\gamma$ accumulation by T cells was detected by immunofluorescence-flow cytometry as previously described [12,17]. Proportions of cytokine producing cells were analyzed within $\mathrm{T}$ cells, gated based on a standard viable forward and side scatter lymphocyte gate and staining for CD3/CD5. Analysis of IL-4, IL-5, and IL-10 was not included in the study because the proportion of positive-expressing cells in freshly PBL was too low $(0.4 \%)$ to accurately assess in the majority subjects, including asthmatics (not shown).

\section{Analysis of proliferation and progenitor numbers}

The number of divisions that IL- $13^{+}$and IFN $-\gamma^{+} \mathrm{T}$ cell progenitors undergo during culture was determined by analysis of carboxyfluorescein diactetate succinimydl ester (CFSE) dilution in CFSE-labeled PBL from female control and female asthmatic subjects, as previously described (12). Average division numbers and minimum progenitor numbers were calculated for experiments of CFSE-labeled PBL as described previously $[12,15]$. See Additional File 1 for details of CFSE analyses.

\section{Statistical analyses}

Distributions of non-normalized data sets were significantly non-Gaussian. Therefore, significance of differences in medians between non-normalized data sets was tested with Mann-Whitney tests (two-tailed). Analyses of accumulation of cytokine ${ }^{+} \mathrm{T}$ cell subsets in culture were performed on data normalized as a percent of the respective day 0 values (day $0=100 \%$ ) because of the variability in the absolute proportions of day 0 cytokine $^{+}$ $\mathrm{T}$ cells. Normalized data were log-transformed to obtain approximate normality of distribution. Significance of differences in transformed (geometric) means was tested by Student's t-tests (two-tailed, corrected for unequal variances). Significance of gender and asthma status on accumulation was tested by 2 -way General Linear Model analyses, with up to 2-way interaction model and planned Tukey-Kramer multiple comparison tests. Statistical analyses were performed using GraphPad Prism (4.0.3; San Diego California USA, http://www.graphpad. com) and Number Cruncher Statistical Systems (NCSS, 2004; J. Hintze, Kaysville, Utah, http://www.NCSS.com) software. 


\section{Results}

Type 1 and type 2 T cell subsets in freshly isolated PBL In freshly isolated human PBL, distinct subsets of $\mathrm{T}$ cells are capable of producing IL-13 $\left(\mathrm{IL}-13^{+}\right)$and IFN- $\gamma$ (IFN$\left.\gamma^{+}\right)$. The median proportions of IL $-13^{+}$and IFN $-\gamma^{+}$ $\mathrm{T}$ cells did not differ significantly between non-asthmatic (control) and atopic asthmatic (asthmatic) subjects (IL-13 ${ }^{+}: 0.8 \%$, interquartile ranges (IQR): $0.5-2.1 \%, n=$ 21 ; and $0.9 \%$, IQR: $0.5-2.5 \%, \mathrm{n}=25$, respectively; $p=$ $0.56)$; IFN $-\gamma^{+}:(8.4 \%$, IQR: $2.2-13.5, n=20$; and 5.4\%, IQR: $2.7-14.0, n=25$, respectively; $p=0.71$ ).

\section{Accumulation of type 1 and type 2 T cell subsets CD3+CD28-mediated stimulation}

To test whether $\mathrm{T}$ cell subsets in freshly isolated PBL differ in their response to antigenic stimulation, $\mathrm{PBL}$ were stimulated with CD3 and CD28 monoclonal antibody to mimic efficient antigenic stimulation by professional antigen-presenting cells (e.g., activated macrophages, dendritic cells). The median proportion of IL- $13^{+} \mathrm{T}$ cells after 5 -day culture with CD3+CD28mediated stimulation did not significantly differ between control subjects and asthmatics (Table 1). In contrast, the median proportion of IFN $-\gamma^{+} \mathrm{T}$ cells after 5-day culture was significantly higher in asthmatics than in control subjects.

After 5-day culture the total number of $\mathrm{T}$ cells from both asthmatic and control subjects increased 400\% above the day 0 number (Figure 1A). The number of IL$13^{+} \mathrm{T}$ cells from both asthmatic and control subjects likewise increased relative to the day 0 numbers, although there was not a significant mean increase in the proportion of $\mathrm{IL}-13^{+} \mathrm{T}$ cells from either group

\section{Table 1 Proportions of IL- $13^{+}$and IFN- $\gamma^{+}$T cells after culture}

\begin{tabular}{|c|c|c|c|c|c|c|}
\hline Stimulus * & Subset & Subjects & Median $^{+}$ & $\mathrm{IQR}^{+}$ & $n$ & $p^{\neq}$ \\
\hline $\mathrm{CD} 3+\mathrm{CD} 28$ & $\mathrm{IL}-13^{+}$ & Control & $0.8 \%$ & $0.6-4.3$ & 17 & 0.67 \\
\hline \multirow[t]{3}{*}{$+\mathrm{IL}-2$} & & Asthma & $1.8 \%$ & $0.5-4.2$ & 18 & \\
\hline & $\mathrm{IFN}-\gamma^{+}$ & Control & $2.9 \%$ & $0.6-7.8$ & 11 & 0.035 \\
\hline & & Asthma & $7.4 \%$ & $5.1-20.2$ & 19 & \\
\hline \multirow[t]{4}{*}{ IL-2 } & $\mathrm{IL}-13^{+}$ & Control & $1.0 \%$ & $0.7-3.2$ & 24 & 0.0004 \\
\hline & & Asthma & $4.5 \%$ & $2.5-5.3$ & 18 & \\
\hline & $\mathrm{IFN}-\gamma^{+}$ & Control & $4.1 \%$ & $2.4-10.3$ & 19 & 0.0076 \\
\hline & & Asthma & $10.7 \%$ & $7.2-24.2$ & 19 & \\
\hline
\end{tabular}

* After 5-day (CD3+CD28+IL-2) or 6-day (IL-2) culture of PBL (anti-IL-12 monoclonal antibody included in all cultures), proportions of cytokineproducing $T$ cells were determined by flow cytometry.

${ }^{+}$Median and $25 \%-75 \%$ interquartile range (IQR) of the proportion of IL-13+ or IFN- $\gamma^{+} \mathrm{T}$ cell subsets.

${ }^{\ddagger} p$-value for the significance of difference between control and asthmatic subjects (two-tailed Mann-Whitney test).
(Figure 1B). There was a significant impact of gender on the results ( $\mathrm{p}=0.0001)$, but no interaction between gender and asthma observed (results of stratified analyses are discussed below in "Gender effects on $\mathrm{T}$ cell subset accumulation" section). The proportion of IFN- $\gamma^{+}$ $\mathrm{T}$ cells decreased during culture for control subjects, but increased for asthmatic subjects, such that changes in proportion were different $(p=0.046)$ between groups (Figure 1C). There was a significant mean increase in number of IFN- $\gamma^{+} \mathrm{T}$ cells during culture for both asthmatic and control subjects, and this increase was greater for asthmatics compared to control subjects $(p=0.041)$. Using starting (day 0) proportions of IL- $13^{+}$and IFN- $\gamma^{+}$ as covariates in Analyses of Covariance (ANCOVA) did not change the significance of the above findings.

\section{IL-4, IL-12 polarization effects}

Under the 'classical Th2-polarization' culture condition of CD3+CD28-mediated stimulation plus IL-2, IL-4, and anti-IL-12, IL- $13^{+} \mathrm{T}$ cells increased significantly in number, with no significant difference between control and asthmatic subjects (Figure 2A). Under the 'classical Th1-polarization' culture condition of CD3+CD28mediated stimulation plus IL- 2 and IL-12, IFN- $\gamma^{+}$ $\mathrm{T}$ cells from control subjects increased in number with a mean zero-change in proportion (Figure $2 \mathrm{~B}$ ), in contrast to that observed in the CD3-stimulated condition in the absence of IL-12 (Figure 1C). The mean change in CD3+CD28+IL-12-stimulated accumulation of IFN$\gamma^{+} \mathrm{T}$ cells was similar for control and asthmatic subjects. Because IFN- $\gamma^{+} \mathrm{T}$ cells from asthmatics accumulate to greater numbers in $\mathrm{CD} 3+\mathrm{CD} 28$-stimulated cultures with IL-2 in the absence of IL-12, the response of $\mathrm{T}$ cells specifically to IL-12 was assessed by comparing IFN $-\gamma^{+} \mathrm{T}$ cell accumulation in cultures with IL- $2+$ IL-12 relative to cultures with IL- $2+$ antiIL-12 (Figure 2C). Relative to the IL-2 + anti-IL-12 condition, IFN $-\gamma^{+} \mathrm{T}$ cell accumulation increased more in cultures with IL-12, with this increase in both number and proportion being significantly greater in control subjects than in asthmatics.

\section{IL-2 stimulated accumulation}

IL- $13^{+} \mathrm{T}$ cells also proliferate in response to IL-2, independent of CD3/antigen-mediated stimulation, preferentially accumulating in cultures relative to the major IL$13^{-} \mathrm{T}$ cell population $(12,15)$. Total $\mathrm{T}$ cell numbers did not significantly change in PBL from both control and asthmatic subjects in cultures with IL-2 (Figure 3A). In PBL stimulated with IL-2, the median proportion of IL$13^{+}$and IFN- $\gamma^{+} \mathrm{T}$ cells after 6 -day culture was significantly higher in asthmatics than in control subjects (Table 1). IL- $13^{+} \mathrm{T}$ cells from both asthmatic and control subjects significantly increased relative to starting day 0 values, and this increase in accumulation was significantly greater in asthmatic than in control subjects 


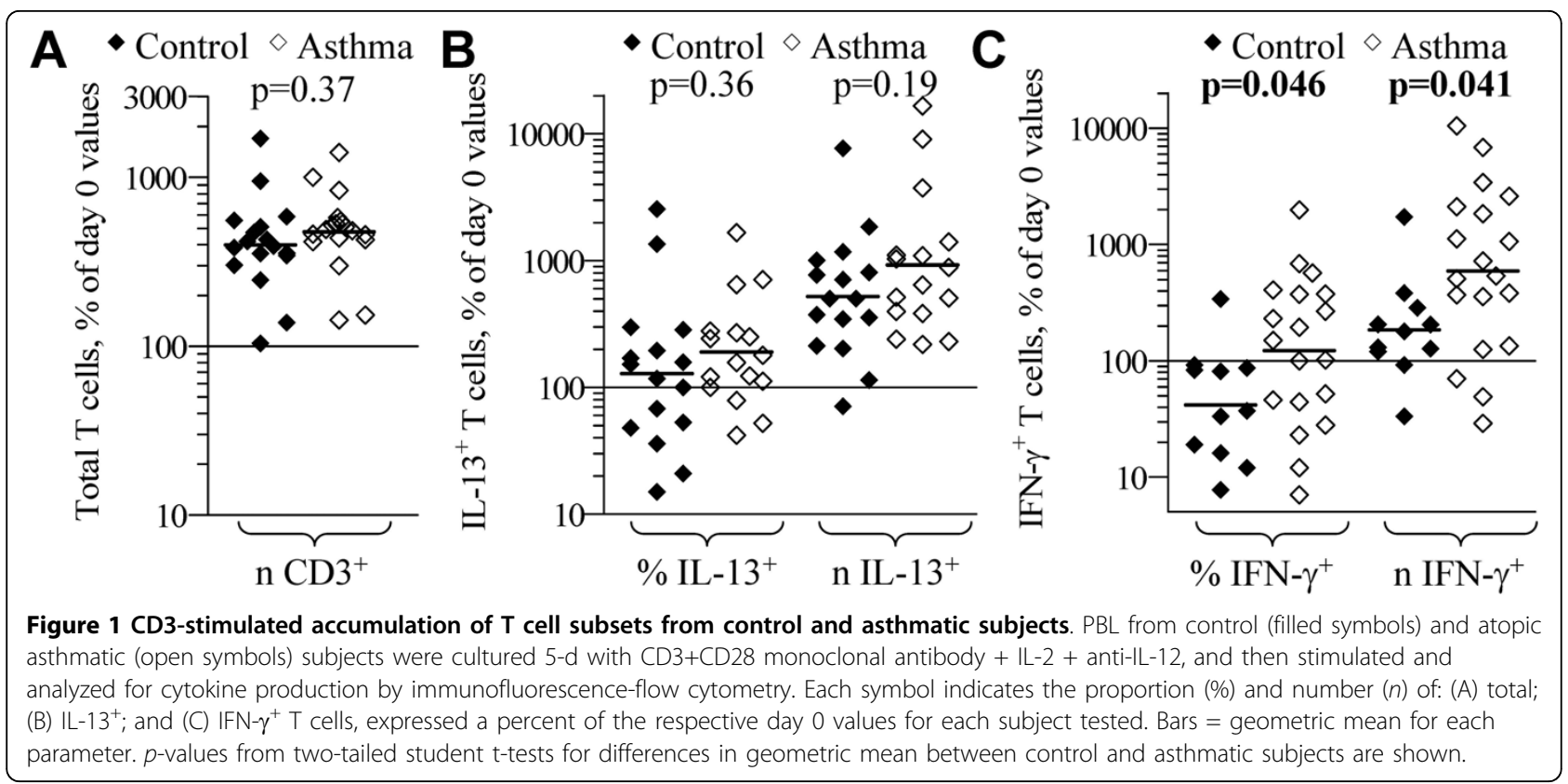

$(p \leq 0.0004)$ (Figure 3b). There was also a significant interaction $(\mathrm{p}=0.003)$ between gender and asthma status for IL-2-stimulated increases in IL-13+ T cells, suggesting gender-specific differences for the observed associations with asthma (see "Gender effects on $\mathrm{T}$ cell subset accumulation" section below for discussion of stratified analyses). In control subjects, IFN $-\gamma^{+} \mathrm{T}$ cells decreased in proportion $(p=0.01)$ and number $(p=$ 0.008 ) in cultures with IL-2 (Figure 3C). In stark contrast, IFN $-\gamma^{+} \mathrm{T}$ cells from asthmatic subjects increased in both proportion $(p=0.007)$ and number $(p=0.008)$, and the differences in accumulation were significantly different $(p \leq 0.0004)$ between the control and asthma groups. For control subjects, IFN- $\gamma^{+}$cells increased in proportion and number only when IL-12 was included in the culture (not shown). A role for IL-12 or IL-23 in the increase in IFN- $\gamma^{+}$in PBL from asthmatics was excluded because IL-12p40-neutralizing monoclonal antibody were included in all cultures. Using starting (day 0) proportions of IL- $13^{+}$and IFN- $\gamma^{+}$as covariates in ANCOVA did not change the significance of the above findings.

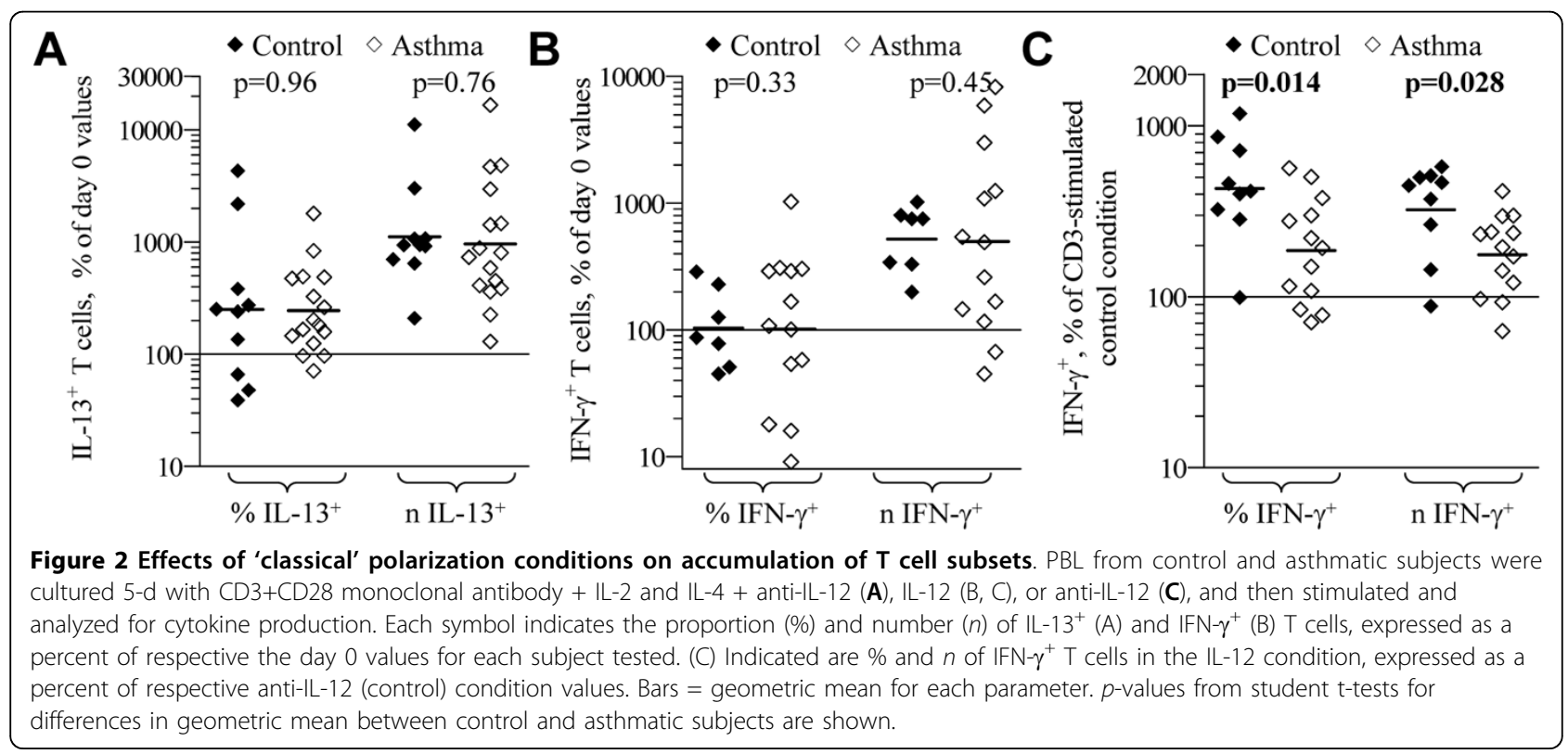




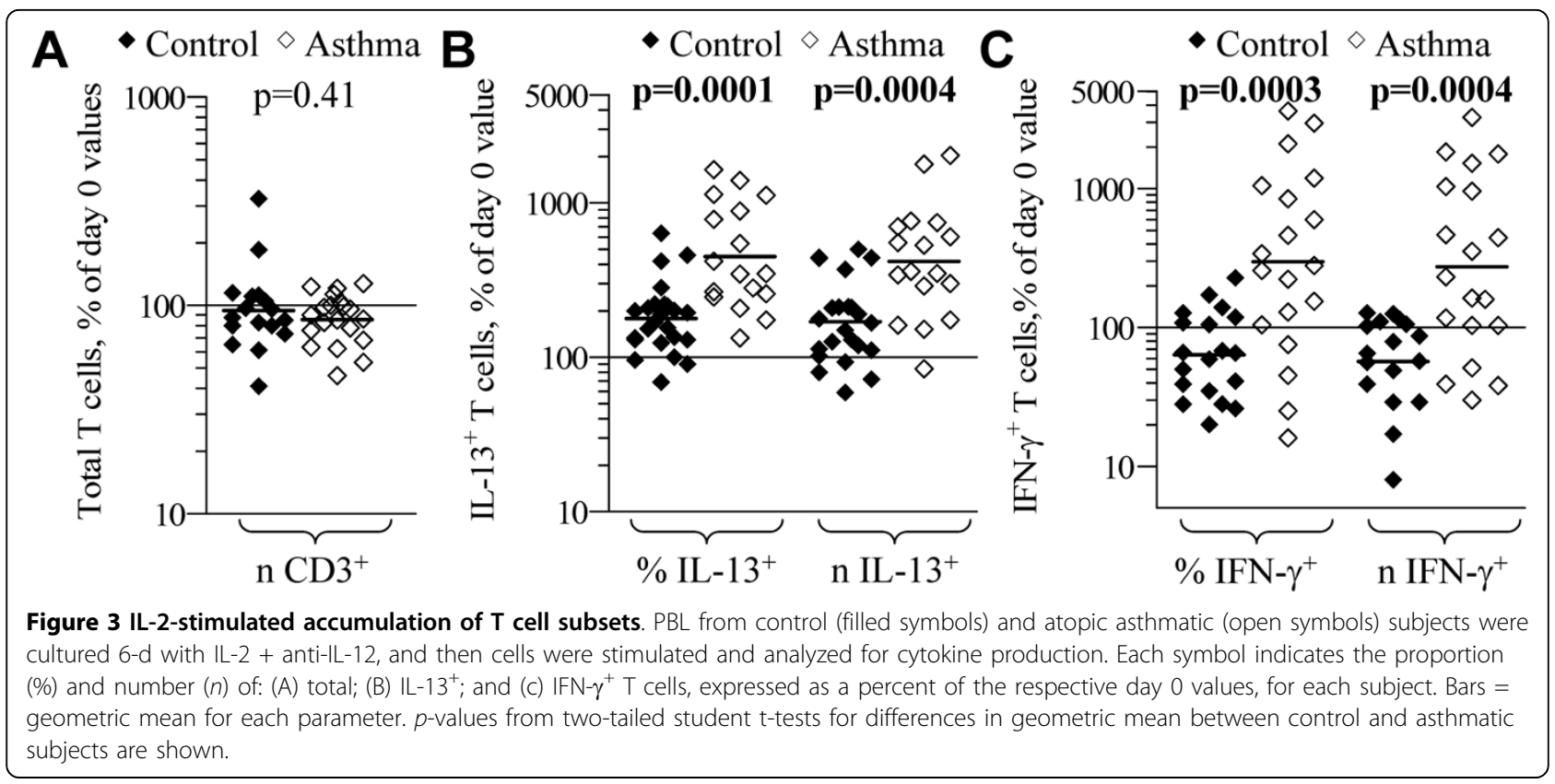

\section{Gender effects on $\mathrm{T}$ cell subset accumulation}

Race and gender may contribute to asthma risk, with asthma being more common in African Americans than in Caucasians (National Center for Health Statistics. Asthma: http://www.cdc.gov/nchs/fastats/asthma.htm. CDC. 2006), and, in adult asthmatics, more common in pre-menopausal females than in males (reviewed by Balzano et al. [18]). The asthma population used in this study consisted of $60 \%$ Caucasian and $40 \%$ AfricanAmericans, and 55\% females and $45 \%$ males. All data were analyzed to consider the cofactors of race and gender. There was no difference between Caucasian and African American asthmatics in accumulation (IL-2and CD3- stimulated) of IL- $13^{+}$or IFN- $\gamma^{+} \mathrm{T}$ cells, and both Caucasian and African American asthmatic groups showed greater accumulation of IL-2-stimulated accumulation of $\mathrm{IL}-13^{+}$and IFN $-\gamma^{+} \mathrm{T}$ cells compared to Caucasian controls (not shown). The number of African American control subjects was not sufficient to enable comparisons between racial groups in control subjects.

The data for IL-2-stimulated accumulation of IL-13 ${ }^{+}$ and IFN $-\gamma^{+} \mathrm{T}$ cell accumulation were stratified to demonstrate the contributions of gender and asthma on accumulation (Figure 4). There was a significant interaction between asthma and gender for IL-2-stimulated accumulation of IL- $13^{+}$T cells $(p=0.003)$ but not IFN$\gamma^{+}$T cells $(p=0.42)$. Female asthmatics had significantly greater IL-2-stimulated accumulation of IL- $13^{+} \mathrm{T}$ cells than both male and female controls ( $p<0.001$ for both) and also male asthmatics $(p<0.01)$. For the 6 experiments in which CD8 staining was available, IL-2-stimulated accumulation of IL- $13^{+} \mathrm{T}$ cells was greater in female vs. males asthmatics for both $\mathrm{CD}^{-}$(mostly CD4 $4^{+}$) and $\mathrm{CD}^{+} \mathrm{T}$ cell subsets (Figure $\mathrm{S} 1$ in Additional File 1). IFN $-\gamma^{+} \mathrm{T}$ cell accumulation was increased in both $\mathrm{CD}^{+}$ and $\mathrm{CD}^{-} \mathrm{T}$ cell subsets in asthmatics regardless of gender (data not shown).

All but one of the female control subjects were atopic, as determined by skin prick tests to a panel of common aeroallergens. The differences between female asthmatics and female controls remained significant $(\mathrm{p}<$ 0.001) when excluding the one nonatopic female control subject (not shown). Skin prick tests were performed on only 6 of the male control subjects, all of whom tested positive. The mean increase in $\mathrm{IL}-13^{+} \mathrm{T}$ cells remained similar for atopic nonasthmatic males compared to atopic nonasthmatic females, as observed for the main analysis not restricted by atopy status (not shown). These results demonstrate that the observed associations for asthma- and gender-specific increases in IL- $13^{+} \mathrm{T}$ cells is a function of atopic asthma per se, rather than a function of atopy status alone.

The difference in IL-2-stimulated accumulation of IL$13^{+}$and IFN- $\gamma^{+} \mathrm{T}$ cells between female and male asthmatics remained significant when data from lung function studies (e.g., methacholine PC20, percent predicted $\mathrm{FEV}_{1}$, \% reversal in $\mathrm{FEV}_{1}$ by albuterol, percent predicted forced vital capacity (FVC), FVC/FEV 1 ) and other factors (age, serum IgE, body mass index) were considered as covariates in GLM analyses (not shown). These covariates were not included in the final GLM models because none of these variables significantly differed between male and female asthmatics, nor correlated with extent of $\mathrm{T}$ cell subset accumulation (see Table S1 

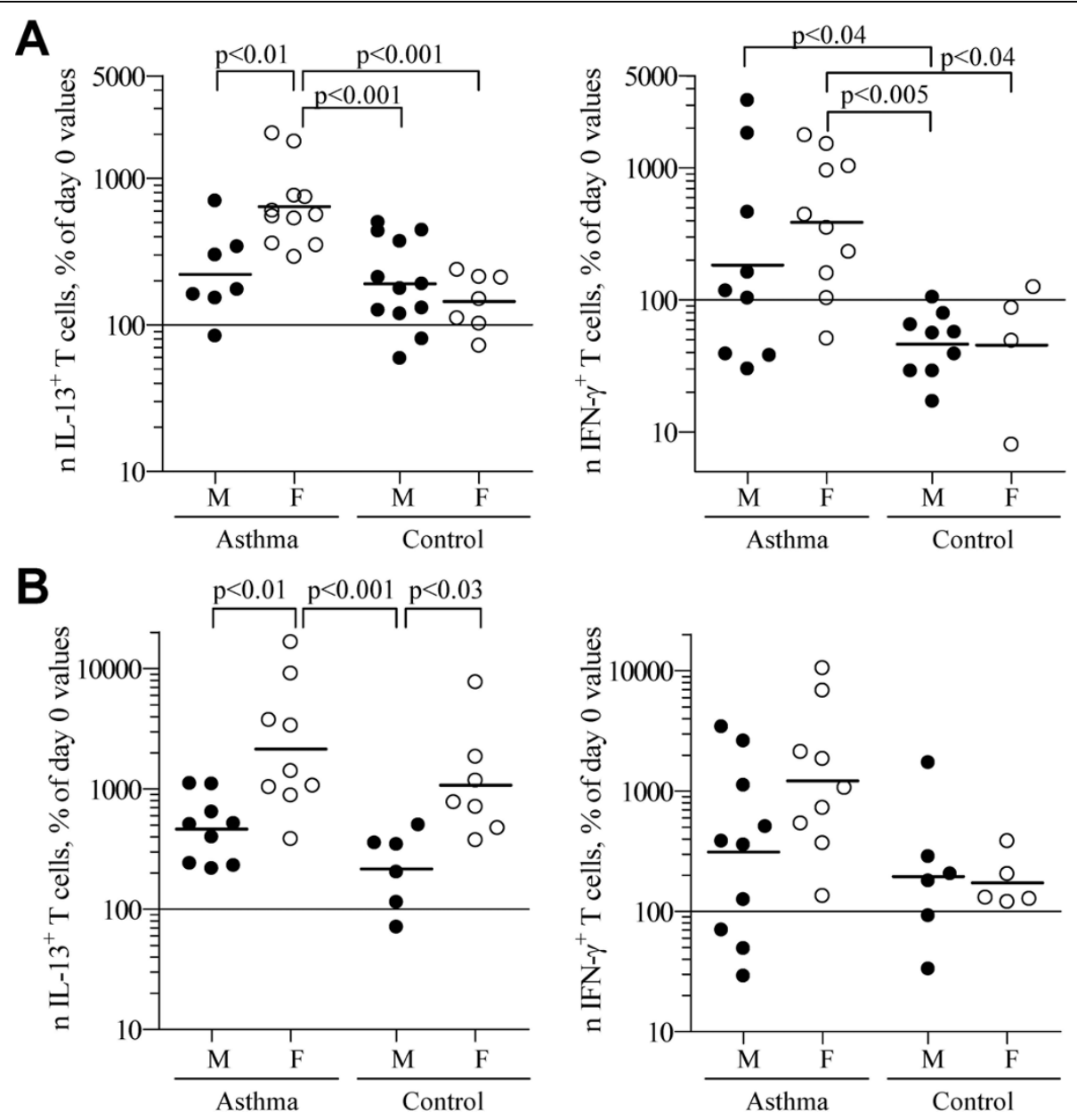

Figure 4 Effects of gender and asthma on T cell subset accumulation. Data obtained in the experiments for Figures 2 and 4 were reanalyzed, including both asthma and gender as independent variables in 2-way General Linear Model analyses of accumulation of IL-13 ${ }^{+}$and IFN- $\gamma^{+} T$ cells. Each symbol indicates the number of: $\mathrm{IL}-13^{+}$(left panels) and IFN- $\gamma^{+}$(right panels) $\mathrm{T}$ cells, expressed as a percent of the respective day 0 values for each subject after (A) 6-d culture with IL-2 + anti-IL-12 or (B) 5-d culture with CD3+CD28monoclonal antibody + IL-2 + anti-IL12. Bars = geometric mean for each parameter. $p$-values from planned Tukey-Kramer multiple comparison tests are shown.

in Additional File 1). For CD3+CD28-stimulated accumulation of IL-13 ${ }^{+} \mathrm{T}$ cells, there was a significant difference between male and female subjects overall $(p=0.0001)$ and within asthmatic $(p<0.01)$ and control $(p<0.03)$ populations, but not between asthma and control populations within the same gender. An influence of gender on CD3+CD28-stimulated accumulation of IFN- $\gamma^{+}$T cells was not detected.

\section{Lack of influence of inhaled corticosteroids}

Although inhaled corticosteroids for asthma control was withheld for at least 12 -h before blood draw, it is still possible that this anti-inflammatory drug may impact the peripheral blood T cells. To control for this potential confounder, two-way ANOVA were performed to adjust for regular inhaled corticosteroid use and gender for $\mathrm{T}$ cell subset accumulation in the asthma population
(Table 2). Regular steroid use did not impact IL-2-stimulated accumulation of $\mathrm{IL}-13^{+}$and IFN $-\gamma^{+} \mathrm{T}$ cells. Regular steroid use tended to decrease CD3+CD28-stimulated accumulation of $\mathrm{IL}-13^{+}$and IFN $-\gamma^{+} \mathrm{T}$ cells, regardless of gender (no interaction effect). This observation actually strengthens the observed increased accumulation of IFN $-\gamma^{+} \mathrm{T}$ cells in asthmatics compared to controls, as regular steroid use would tend to lower the mean accumulation of IFN $-\gamma^{+} \mathrm{T}$ cells in the asthma population.

To confirm that asthma status, and not differences in steroid use, determines the increased accumulation of IL- $13^{+}$and IFN $-\gamma^{+}$T cells, female asthmatics and controls were compared, restricting the analysis to those subjects that do not use inhaled steroids. The significance levels for differences between female asthmatics and controls for IL-2-stimulated accumulation of IL-13 ${ }^{+}$ 
Table 2 Impact of regular inhaled corticosteroid use on T cell subset accumulation

\begin{tabular}{|c|c|c|c|c|c|c|c|c|c|}
\hline \multirow[t]{2}{*}{ Culture stimulus } & \multirow[t]{2}{*}{$T$ cell subset } & \multicolumn{2}{|c|}{ Asthma group } & \multicolumn{3}{|c|}{ Accumulation, $\%$ of day 0 numbers * } & \multicolumn{3}{|c|}{ p-value $^{\dagger}$} \\
\hline & & Gender & Steroid ${ }^{\circ}$ & Geo. Mean & Geo. Mean \pm S.D. & $\mathrm{n}$ & Gender & Steroid & Interaction \\
\hline \multirow[t]{8}{*}{$\overline{I L-2}$} & $\mathrm{IL}-13^{+}$ & Female & No & 622 & $326-1184$ & 6 & 0.0016 & 0.16 & 0.22 \\
\hline & & & Yes & 662 & $342-1280$ & 5 & & & \\
\hline & & Male & No & 116 & $73-184$ & 2 & & & \\
\hline & & & Yes & 285 & $155-525$ & 5 & & & \\
\hline & $\mathrm{IFN}-\gamma^{+}$ & Female & No & 677 & $229-1994$ & 6 & 0.41 & 0.28 & 0.40 \\
\hline & & & Yes & 170 & $69-420$ & 4 & & & \\
\hline & & Male & No & 206 & $101-423$ & 3 & & & \\
\hline & & & Yes & 173 & $21-1415$ & 6 & & & \\
\hline $\mathrm{CD} 3+\mathrm{CD} 28$ & $\mid \mathrm{L}-13^{+}$ & Female & No & 5427 & $1281-22,996$ & 3 & 0.0016 & 0.044 & 0.33 \\
\hline \multirow[t]{7}{*}{$+\mid \mathrm{IL}-2$} & & & Yes & 1352 & $571-3,201$ & 6 & & & \\
\hline & & Male & No & 656 & $393-1,094$ & 3 & & & \\
\hline & & & Yes & 388 & $204-738$ & 6 & & & \\
\hline & $\mathrm{IFN}-\gamma^{+}$ & Female & No & 3730 & $886-15,702$ & 3 & 0.073 & 0.023 & 0.98 \\
\hline & & & Yes & 691 & $241-1,982$ & 6 & & & \\
\hline & & Male & No & 1035 & $396-2,707$ & 3 & & & \\
\hline & & & Yes & 186 & $36-962$ & 7 & & & \\
\hline
\end{tabular}

* Two-way General Linear Model analysis was performed to adjust for the impact of regular steroid use and gender on accumulation of T cell subsets from asthmatic subjects. Geo. Mean = geometric mean for the numbers of IL-13+ or IFN- $\gamma+\mathrm{T}$ cells relative to the respective day 0 numbers after culture with the indicated culture stimulus. S.D. = standard deviation.

${ }^{\dagger}$ The significance of differences in geometric mean between males and females (gender) and between asthma subjects that use or don't regularly use inhaled steroids (steroid), and the significance of interaction between gender and steroid effects.

- Indicates whether asthma subjects regularly use inhaled corticosteroids for asthma control. Note that all asthma subjects refrained from using asthma control medications 12-h before blood draw. No subjects regularly used oral corticosteroids for asthma control.

and IFN- $\gamma^{+} \mathrm{T}$ cells and CD3+CD28-stimulated accumulation of IL- $13^{+}$and IFN $-\gamma^{+} \mathrm{T}$ cells were $\mathrm{p}=0.0003$, $0.08,0.006$, and 0.004 respectively (data not shown). Overall these data suggest that regular steroid use before the 12-h withdrawal of asthma-control medications do not impact the significance of the findings in this study.

\section{Mechanisms mediating differences in accumulation}

Previous studies demonstrated that IL-2 stimulates accumulation of $\mathrm{IL}-13^{+} \mathrm{T}$ cells by preferentially inducing proliferation of IL-13 ${ }^{+} \mathrm{T}$ cells $[12,15]$. A potential mechanism to explain the greater accumulation of IL-13 ${ }^{+}$in female asthmatics is a difference in IL-2-stimulated proliferation. Representative plots of division numbers (determined by CFSE fluorescence peaks) and the proportion of IL- $13^{+}$or IL-13- $\mathrm{T}$ cells that had undergone that number of divisions are shown in Figure 5A. In IL2 -stimulated cultures, most $\mathrm{IL}-13^{+} \mathrm{T}$ cells from female control and asthmatic subjects underwent approximately 4-5 divisions in 6 days, whereas few IL-13- $\mathrm{T}$ cells divided at all. There was no significant difference between female control and asthmatic subjects for the average number of divisions by IL-13 ${ }^{+} \mathrm{T}$ cells (Figure 5B). In CD3+CD28-stimulated cultures, IL-13 ${ }^{+}$and IL$13^{-} \mathrm{T}$ cells proliferated to a similar extent, undergoing 4-6 divisions in 5 days, with no significant differences between control and asthmatic subjects (not shown).
The theoretical maximum increase in $\mathrm{IL}-13^{+} \mathrm{T}$ cells expected during culture, on the assumption that no IL-13 ${ }^{+}$ $\mathrm{T}$ cells are lost (via apoptosis or differentiation), can be calculated as $2^{\text {average division number }}$. The actual increase in the number of IL-13 ${ }^{+} \mathrm{T}$ cells from control subjects was $87 \pm 14 \%$ lower $(n=6)$ than the theoretical maximum increase; the actual increase in IL- $13^{+} \mathrm{T}$ cells from asthmatics was $43 \pm 35 \%$ lower $(n=6)$ than the theoretical maximum, significantly lower than that for control subjects $(p=0.03)$. These data indicate that during culture there are losses of the progenitors of $\mathrm{IL}-13^{+} \mathrm{T}$ cells, and that this loss of progenitors is greater in female control subjects than in female asthmatics (Figure 5B). Indeed, in cultures derived from female asthmatics, few $\mathrm{IL}-13^{+} \mathrm{T}$ cell progenitors are lost-approximately one-quarter the loss of progenitors that occurs for control subjects. There were no significant differences between male asthmatics and male controls (and male and female controls overall) for any of these CFSE-derived parameters (not shown). Therefore, reduced loss of IL- $13^{+} \mathrm{T}$ cells rather than increased proliferation is responsible for increased accumulation of IL-13 ${ }^{+} \mathrm{T}$ cells in PBL from female asthmatics.

IFN $-\gamma^{+} \mathrm{T}$ cells from asthmatics did not proliferate more than those from control subjects (Figure $5 \mathrm{~B}$ ). The majority $(\sim 80 \%)$ of IFN- $\gamma^{+} \mathrm{T}$ cell progenitors from control subjects were lost during culture of PBL from control subjects. As with IL $-13^{+} \mathrm{T}$ cells, the loss of IFN $-\gamma^{+} \mathrm{T}$ cell 


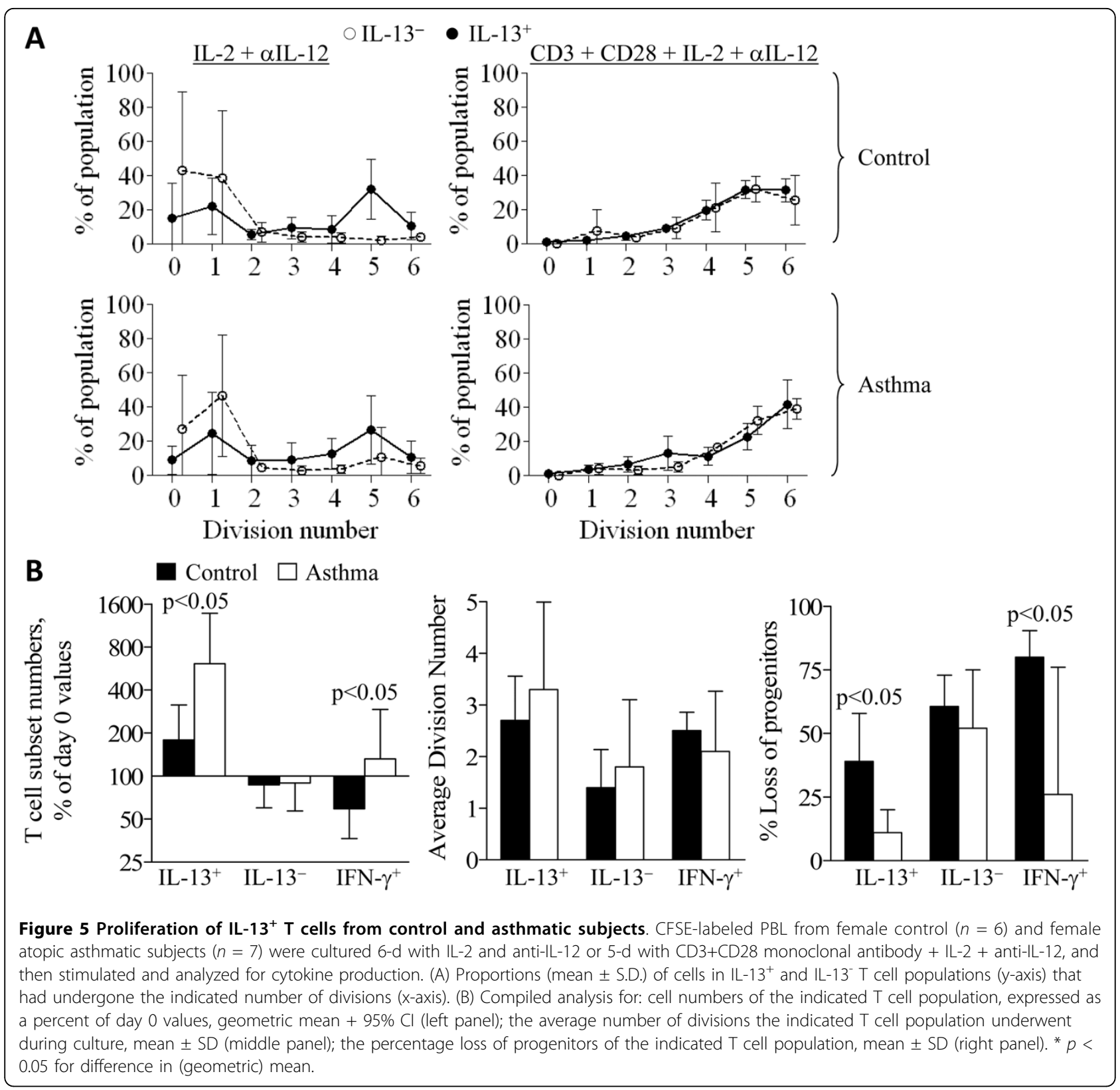

progenitors is significantly reduced in asthmatic subjects. Therefore, the increased accumulation of the IFN $-\gamma^{+}$ $\mathrm{T}$ cell subset from asthmatics, relative to control subjects, is a function of increased maintenance of $\mathrm{T}$ cell subset progenitors rather than enhanced proliferation.

\section{Discussion}

Our study provides the first evidence to date that $\mathrm{T}$ cells from atopic asthmatic and nonasthmatic control subjects differ in their accumulation of $\mathrm{T}$ cell subsets in response to $\mathrm{CD} 3+\mathrm{CD} 28$-mediated and antigen-independent stimulation. Moreover, gender plays a significant role in determining these responses in type $2 \mathrm{~T}$ cell accumulation.
IL-2 stimulated increases in IL- $13^{+} \mathrm{T}$ cells were significantly higher in PBL from asthmatics than in PBL from control subjects, and this increase is almost totally attributable to the female population of asthmatics studied. That the increased accumulation of $\mathrm{IL}-13^{+} \mathrm{T}$ cells was observed in female but not male asthmatics, and the association was maintained when analysis was restricted to only atopic subjects, indicates that the effect was a function of asthma and not atopy per se. Whether there is also an effect of atopy per se on accumulation of IL-13+ T cells should be tested next, by comparing nonatopic nonasthmatic and atopic nonasthmatic healthy control subjects. CD3+CD28-stimulated accumulation of 
IL $-13^{+} \mathrm{T}$ cells was also greater in female subjects, but was not influenced by asthma status. IFN- $\gamma^{+} \mathrm{T}$ cell accumulation, when stimulated by either CD3+CD28 or IL-2, was significantly greater in cells from asthmatics relative to controls, with no effect of gender. Interestingly, in "Th1-polarizing" conditions including IL-12, IFN- $\gamma+$ $\mathrm{T}$ cells increased to similar extents in both asthma and control groups. We would hypothesize that the impact of IL-12 is partially redundant. In cultures with IL-12, existing IFN+ cells survive to a greater extent than in the absence of IL-12 for controls, but in asthmatics survival is already near its maximal limit so as to not be further increased by IL-12.

Unlike the majority of T cells (IL- $13^{-}$and IFN- $\gamma^{+}$subsets), IL-13 ${ }^{+} \mathrm{T}$ cells increase in number and proportion when stimulated with IL-2, even in the absence of antigenic stimulation. This accumulation occurs via selective proliferation of the IL-13 ${ }^{+} \mathrm{T}$ cell subset $[12,15]$. In female asthmatic subjects, IL- $13^{+} \mathrm{T}$ cells accumulate to even greater numbers, with about a 4-fold greater increase than that observed in female control and male asthmatic subjects. CFSE analyses demonstrate the mechanism is not by a further increase in IL-2-stimulated proliferation, but rather via a reduction in the loss of $\mathrm{IL}-13^{+} \mathrm{T}$ cells during culture.

Our data demonstrating enhanced accumulation of not only IL $-13^{+}$but also IFN $-\gamma^{+} \mathrm{T}$ cells from asthmatic subjects in response to IL-2 suggest the importance of antigen-independent stimulation of $\mathrm{T}$ cells in asthma. Cytokine-stimulated (bystander) accumulation of $\mathrm{T}$ cells may potentially explain allergen-independent sensitization in asthmatics, e.g., respiratory infection leading to an IL-2- or IL-15-induced proliferation of resident memory, viral antigen-non-specific, allergen-specific type $2 \mathrm{~T}$ cells, conditions which have been speculated to be relevant to the development of asthma [19]. Viral infections have been implicated in asthma pathogenesis and exacerbations by numerous epidemiologic studies, although limited mechanistic insight exists $[1,3,4,7,8]$. Pathogens (bacteria, virus) induce cytokine production by monocytes, macrophages, and dendritic cells (i.e., monocytic cells). Tissue damage (e.g., products of necrotic cells; endothelins released by endothelia or epithelia, platelet-derived factors), independent of pathogen infection, can also induce cytokine production by monocytic cells $[20,21]$. IL-15, a cytokine produced by monocytic cells, is capable of inducing antigen-independent, bystander proliferation of IL- $13^{+} \mathrm{T}$ cells (unpublished observations). These bystander events need not necessarily take place in the airways. They may also occur in the lymph nodes that drain the lungs where both previously activated memory cells and naïve, type $2 \mathrm{~T}$ cells could either be increased in number prior to being stimulated by allergen or trafficking to the lungs. Thus, although starting numbers of $\mathrm{IL}-13^{+} \mathrm{T}$ cells did not significantly differ between asthmatics and non-asthmatics, enhanced bystander accumulation of type $2 \mathrm{~T}$ cells may nevertheless lead to an acute increase in numbers of $\mathrm{IL}-13^{+} \mathrm{T}$ cells in asthmatics during allergen- or pathogen- induced immune responses.

Increased accumulation of both IL- $13^{+}$and IFN- $\gamma^{+}$in asthmatics contradicts the Th2 hypothesis of asthma, yet is consistent with observations of IFN- $\gamma$ being elevated (with type 2 cytokines) in some asthmatics [4,5]. It has been suggested that microbial infections can contribute to the development of allergic asthma, as well as to exacerbations in subjects with established asthma $[1,3,4,7,8]$. In asthmatic compared to nonasthmatic subjects, microbespecific IFN $-\gamma^{+} \mathrm{T}$ cells can increase to greater numbers during infection. Additionally, non-microbe specific IFN$\gamma^{+}$T cells could also increase in asthmatics, potentially increasing any allergen-specific IFN- $\gamma^{+} \mathrm{T}$ cells as well. An acute increase in IFN- $\gamma$ production during an allergic reaction, or reaction to microbial infection, could exacerbate inflammation in asthmatics by increasing the recruitment and activation of immune cells [6].

The mechanism contributing to gender differences in $\mathrm{IL}-13^{+} \mathrm{T}$ cell accumulation is unclear. Between post-puberty and pre-menopause years, females have a higher incidence of developing asthma than males (reviewed by Balzano et al. [18]). However, during pre-puberty, asthma development tends to occur somewhat more frequently in boys. A portion of adult, asthmatic women also experience perimenstrual worsening of asthma symptoms [22]. These observations suggest the involvement of female sex hormones in the increased accumulation of $\mathrm{IL}-13^{+} \mathrm{T}$ cells. Potential explanations for enhanced IL- $13^{+} \mathrm{T}$ cell accumulation selectively in female asthmatics is an interaction between high levels of female sex hormones and the asthma/atopic environment or asthma/atopy susceptibility genetic polymorphisms. The effects of gender and asthma on IL- $13^{+} \mathrm{T}$ cells could be either from epigenetic, developmental imprinting from continuous hormone exposure, or, alternatively, from acute stimulation by hormones before blood draw. Interestingly, increased accumulation of IL- $13^{+} \mathrm{T}$ cells under CD3+CD28-stimulatory conditions was also observed in females, but was in this case independent of asthma status. It is tempting to speculate if hormonal-driven epigenetic changes to $\mathrm{IL}-13^{+} \mathrm{T}$ cells in females may have broader consequences for susceptibility to type $2 \mathrm{~T}$ cell-associated autoimmune diseases that predominantly occur in females, e.g., lupus and multiple sclerosis.

Decreased numbers of regulatory $\mathrm{T}$ cells have been hypothesized to contribute to the development of asthma [11]. Corticosteroid use is suggested to decrease the development of adaptive IL-10-producing $T_{R} 1$ regulatory $\mathrm{T}$ cells [11]. Perhaps female sex hormones may also contribute to decrease $T_{R} 1$ development and 
subsequent hyperresponsiveness of IL- $13^{+} \mathrm{T}$ cells in female asthmatics. The main mechanism described for inhibition of $\mathrm{T}$ cell accumulation by regulatory $\mathrm{T}$ cells is inhibition of proliferation. Increased accumulation of IL$13^{+}$and IFN- $\gamma^{+} \mathrm{T}$ cells in asthmatics resulted from decreased loss of cytokine ${ }^{+}$cells rather than increased proliferation relative to controls. Also, increased accumulation of IL-13 ${ }^{+} \mathrm{T}$ cells in female asthmatics was observed only for the IL-2-stimulated condition and not the $\mathrm{CD} 3+\mathrm{CD} 28$-mediated condition. For these reasons it seems less likely that differences in regulatory $\mathrm{T}$ cells account for the observed increased accumulation of $\mathrm{T}$ cell subsets in asthmatics.

\section{Conclusions}

In conclusion, our data demonstrate that both type 1 and type $2 \mathrm{~T}$ cell subsets increase to a greater extent in asthmatic than control subjects in response to antigenindependent, cytokine-mediated stimulation, with the increased accumulation of type $2 \mathrm{~T}$ cells exclusively in female asthmatics. These results provide explanations for the higher frequency of adult asthma in females and for the apparently paradoxical increase of both IFN- $\gamma$ and IL-13 in the lungs of a subset of allergen-challenged asthmatics.

\section{Additional material}

Additional file 1: methods, table S1, figure S1, additional file references.

\begin{abstract}
Abbreviations
ANCOVA: analysis of covariance; CFSE: carboxyfluorescein diactetate succinimydl ester; FEV $_{1}$ f forced expiratory volume at 1-sec; FVC: forced vital capacity; GLM: General Linear Model; IFN: interferon; IL: interleukin; IQR: interquartile range; $\mathrm{PBL}$ : peripheral blood lymphocytes; $\mathrm{PC}_{20}$ : provocative concentration of methacholine causing 20\% fall in $\mathrm{FEV}_{1}$; PMA: phorbol myristate acetate; PP: percent predicted
\end{abstract}

\section{Acknowledgements}

This manuscript is dedicated to the memory of Dr. Bice Perussia, without whom this study would never have originated. This work was supported in part by grants from the National Institute of Health (HL58506 to R.B.P. and HL69167 to E.R.B.). The funding bodies played no role in the collection, analysis, and interpretation of data; in the writing of the manuscript; or in the decision to submit the manuscript for publication. The authors declare no conflicting financial interests.

\section{Authors' contributions}

MJL and RBP wrote the manuscript. MJL and SF performed all experiments. SF, SPP. SF, ERB, and SPP recruited and characterized clinical status of subjects. All authors contributed to experimental design, data interpretation and formation of the manuscript in its final form.

\section{Competing interests}

The authors declare that they have no competing interests. All contributions for this manuscript by MJL were completed at Wake Forest University Health Sciences. MJL is currently employed by Centocor R\&D.
Received: 30 April 2010 Accepted: 28 July 2010 Published: 28 July 2010

\section{References}

1. Busse WW, Lemanske RF: Asthma. N Engl J Med 2001, 344:350-362.

2. Colavita AM, Reinach AJ, Peters SP: Contributing factors to the pathobiology of asthma. The Th1/Th2 paradigm. Clin Chest Med 2000, 21:263-77, viii.

3. Holgate ST: Pathogenesis of asthma. Clin Exp Allergy 2008, 38:872-897.

4. Holtzman MJ, Sampath D, Castro M, Look DC, Jayaraman S: The one-two of T helper cells: does interferon-gamma knock out the Th2 hypothesis for asthma? Am J Respir Cell Mol Biol 1996, 14:316-318.

5. Krug N, Madden J, Redington AE, Lackie P, Djukanovic R, Schauer U, Holgate ST, Frew AJ, Howarth PH: T-cell cytokine profile evaluated at the single cell level in BAL and blood in allergic asthma. Am J Respir Cell Mol Biol 1996, 14:319-326.

6. Randolph DA, Stephens R, Carruthers CJ, Chaplin DD: Cooperation between Th1 and Th2 cells in a murine model of eosinophilic airway inflammation. J Clin Invest 1999, 104:1021-1029.

7. Shaver JR, Zangrilli JG, Cho SK, Cirelli RA, Pollice M, Hastie AT, Fish JE, Peters SP: Kinetics of the development and recovery of the lung from IgE-mediated inflammation: dissociation of pulmonary eosinophilia, lung injury, and eosinophil-active cytokines. Am J Respir Crit Care Med 1997, 155:442-8.

8. Strachan DP: Hay fever, hygiene, and household size. Bmj 1989, 299:1259-1260.

9. Druilhe A, Wallaert B, Tsicopoulos A, Lapae Silva JR, Tillie-Leblond I, Tonnel AB, Pretolani M: Apoptosis, proliferation, and expression of BCl-2, Fas, and Fas ligand in bronchial biopsies from asthmatics. Am J Respir Cell Mol Biol 1998, 19:747-757.

10. Valerius T, Repp R, Kalden JR, Platzer E: Effects of IFN on human eosinophils in comparison with other cytokines. A novel class of eosinophil activators with delayed onset of action. J Immunol 1990, 145:2950-2958.

11. Stock P, DeKruyff RH, Umetsu DT: Inhibition of the allergic response by regulatory T cells. Curr Opin Allergy Clin Immunol 2006, 6:12-16.

12. Loza MJ, Perussia B: Final steps of natural killer cell maturation: a model for type 1-type 2 differentiation? Nat Immunol 2001, 2:917-924.

13. Loza MJ, Metelitsa LS, Perussia B: NKT and T cells: coordinate regulation of NK-like phenotype and cytokine production. Eur J Immunol 2002, 32:3453-3462.

14. Loza MJ, Perussia B: Peripheral immature CD2-/low T cell development from type 2 to type 1 cytokine production. J Immunol 2002, 169:3061-3068.

15. Loza MJ, Perussia B: Accumulation of type 2 cytokine+ T cells: differentiation-independent proliferation of pre-existing type $2 \mathrm{~T}$ cells. Eur J Immunol 2003, 33:939-949.

16. Loza MJ, Foster S, Peters SP, Penn RB: Interactive effects of steroids and beta-agonists on accumulation of type $2 \mathrm{~T}$ cells. J Allergy Clin Immunol 2008, 121:750-755

17. Loza MJ, Faust JS, Perussia B: Multiple color immunofluorescence for cytokine detection at the single cell level. Methods Mol Biol 2000, 121:193-209.

18. Balzano G, Fuschillo S, Melillo G, Bonini S: Asthma and sex hormones. Allergy 2001, 56:13-20.

19. Loza MJ, Peters SP, Penn RB: Atopy, asthma, and experimental approaches based on the linear model of T cell maturation. Clin Exp Allergy 2005, 35:8-17.

20. Gough PJ, Gordon S: The role of scavenger receptors in the innate immune system. Microbes Infect 2000, 2:305-311.

21. Janeway CA Jr: The immune system evolved to discriminate infectious nonself from noninfectious self. Immunol Today 1992, 13:11-16.

22. Vrieze A, Postma DS, Kerstiens HA: Perimenstrual asthma: a syndrome without known cause or cure. J Allergy Clin Immunol 2003, 112:271-282.

doi:10.1186/1465-9921-11-103

Cite this article as: Loza et al:: Asthma and gender impact accumulation of T cell subtypes. Respiratory Research 2010 11:103. 